\title{
立川断層における深い地盤構造の探査
}

\author{
東京工業大学大学院総合理工学研究科* 山中浩 明 - 栗田勝実 \\ 山田伸之・瀬尾和大
}

\section{Exploration of Deep Sedimentary Layers around the Tachikawa Fault, Japan}

\author{
Hiroaki Yamanaka, Katsumi Kurita, Nobuyuki Yamada and Kazuoh Seo \\ Interdisciplinary Graduate School of Science and Engineering, Tokyo Institute of \\ Technology, 4259 Nagatsuta, Midori-ku, Yokohama, Kanagawa 226-8502, Japan
}

(Received July 13, 1999; Accepted, October, 13, 1999)

\begin{abstract}
Tachikawa fault is an active fault located in the western part of the Tokyo Metropolitan area. A structure of deep sedimentary layers around the fault was explored by microtremor array measurements and an analysis of existing seismic refraction data for the purpose of estimating its effects on earthquake ground motion. It was found from the microtremor array measurements that a basement depth in S-wave profile at down-thrown side of the fault is larger than that at up-thrown side with depth difference of $1.6 \mathrm{~km}$. A two-dimensional model was constructed using the explosion data and the depth data on the sediments derived from the microtremor array measurements. Travel times of initial P-wave for the proposed model calculated by a finite difference ray tracing fit the observed travel times better than the model from a conventional time term analysis. We evaluated spatial variations of amplification of earthquake ground motion in the proposed model using a 2D finite difference numerical simulation. It was found that ground motion in the down-thrown side is amplified due to effects of the basement step.
\end{abstract}

Key words: Seismic refraction survey, Ray tracing, Tachikawa fault, Microtoremor array, S-wave profile.

§1.はじめに

周期 1 秒以上のやや長周期地震動の予測やサイス ミックマイクロゾーニングを行う際には, $5 \mathrm{~km} / \mathrm{s}$ 程度 以上の $\mathrm{P}$ 波速度を有する地款の最上層までの地盤の構 造を知ることが重要となる．わが国においては，1970 年代後半からいくつかの地域で深い地盤を対象とした地 震探查が実施されている．とくに，大阪平野や関東平野 では比較的高い密度で人工地震探査が行われ，深い地盤 の 3 次元的な構造モデルも提案されている[例えば, 香 川・他 (1993), KohKetsu and Higashi (1992)].こう して得られた地盤構造データは堆積平野で観測された地 震動の特性を評価するために用いられ，最近では観測さ れたやや長周期地震動特性が数值モデリングによってあ る程度再現できるようになっている [例えば，佐藤・他

* ₹226-8502 神奈川県横浜市緑区長津田町 4259
(1997)]. しかしながら，上記のような大規模な平野で行 われている地震探查の多くは屈折法に基づくあので, 平 野の大局的な地下構造を知ることに主眼が置かれてお り，それらの観測結果から堆積首に覆われた基盤上面に 存在する断層などの急激な地下構造の変化を検出するこ とは難しい. さらに, 地盤の 3 次元構造モデルを作成す る際には空間的なスムージング等の処理が行われ, 急激 な地下構造の変化は丸められてしまうことあある.

基盤構造に急激な变化がある場合には, その周辺で観 測される地震動は大きくその影響を受けており，基盤の 急激な変化の影響は無視できないものであることが指摘 されている [例えば, KASUGA and IRIKURA (1982)]. 実 際に, 1995 年兵庫県南部地震の際に被害が激しい地域 が帯状の分布となった原因のひとつに, 基盤の段差構造 による地震波の增幅的干涉が多くの研究者によって指摘 されている [例えば, 川瀬・他 (1996)]. 多くの堆積盆地 
では盆地の沈降や山地の隆起があり, その周縁部には段 差構造に代表される急激な基盤構造の変化が存在してい ると考えられる.したがって, 兵庫県南部地震の被害分 布は, 神戸地域の地盤による特殊な現象ではなく, 堆積 盆地周縁部では一般的なことである可能性がある。この ように，断首などのように地下構造に急な変化があると 予想される地域では, 地震動評価を行う際に用いる地下 構造モデルの作成には十分に注意を払う必要があると考 えられる。

上記のような基盤の段差構造における地震波の挙動を 明らかにすることを目的として，東京都西部に存在する 立川断層周辺において地震動のアレイ観測を行っている [栗田・山中 (1998)]. 立川断層は, 再現期間が数干年の 活断層であると考えられており [活断層研究会 (1980)], 地形学的調查によれば [山崎 (1978)], 地表付近では, 南西落ちの断層であることが確認されている. 一方, 重 力探查の結果では [萩原・他 (1988a)], 基盤に北東落ち の段差が推定されている.このように，立川断層周辺の 地下構造は, 今だ不確かな部分も残されている.

本研究は, 立川断層周辺での地震波の挙動を理解する ための基礎的資料を得ることを目的として, 微動アレイ 観測および既往の屈折法人工地震観測デー夕の解析を行 い, 深い地盤の構造を明らかにするものである.

\section{§ 2. 微動アレイ観測}

\section{1 観測}

Fig. 1 に示すように, 微動のアレイ観測は, 立川断層 を挟んで東大和市 (以後, HYT) と昭島市 (以後, AKS) を中心とした 2 地点で実施された. 両地点において,

Fig. 2 に示すように大きさの異なる 2 つのアレイが設け られた. 両地点でのアレイの観測点間隔は $0.2 \sim 3 \mathrm{~km}$ で ある. HYT でのアレイ観測には, 固有周期を 10 秒に設 定した上下成分地震計 (PELS), 增幅器, 14 ビットのレ コーダー, クロック信号発生器から構成される 7 組の機 器を用いた。 クロック信号は観測の前後で GPS 時刻信 号により校正されており, 誤差は 0.01 秒以下であった。 一方, AKS でのアレイ観測では, 7 組の上下成分加速度 計［工藤・他(1997)］と増幅器つきの 16 ビットのレ コーダーが用いられた。記録の同期は GPS 時刻信号に より校正されたクロック信号により行われ，時刻の精度 は 0.002 秒以下であった. AKS と HYT で用いられた 観測システムでは, 同時微動観測により周期 5 秒程度ま では両者の周期特性にほとんど差がないことを確認し た. 両地点での観測に際して, 地震計からの出力は 0.01 秒間隔にサンプリングされ，約 1 時間記録された。

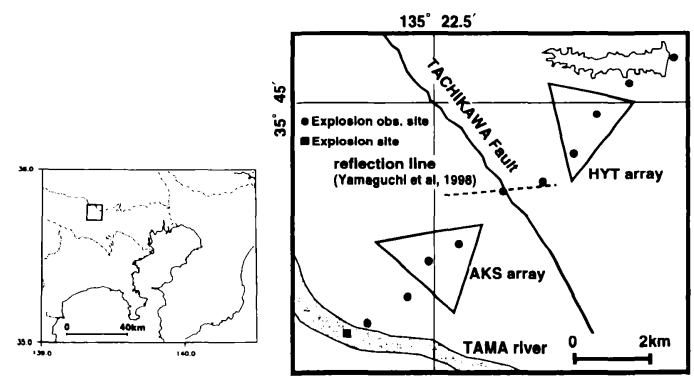

Fig. 1. Locations of the Tachikawa fault, observation sites for explosion seismic survey and arrays for microtremor measurements. A solid square and solid circles show explosion site and its observation stations. Large triangles indicate microtremor arrays. The location of the Tachikawa fault is reproduced from active fault map in urban area (OME) published by Geographical Survey Institute, Japan. A broken line indicates seismic reflection surveying line by YamaGuchi et al. (1998).
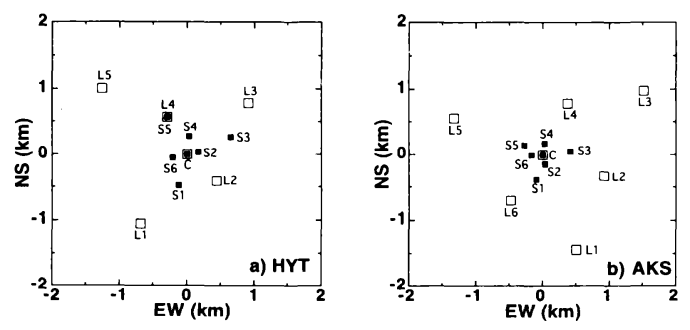

Fig. 2. Configurations of stations in microtremor arrays at a) HYT and b) AKS. Solid and open squares indicate locations of stations in small and large arrays.

\section{2 観測結果}

解析では, 全記録を人工的ノイズの少ない約 330 秒間 の記録からなる複数のデータに分割した。なお，加速度 記録について速度に積分した，さらに，速度波形を目視 して，パルス状のノイズの少ない部分を解析に用いるこ とにした. 分割したそれぞれのファイルに対して CAPON (1969) の方法により周波数一波数スペクトル解析を 行った. さらに, 各データファイルに対して得られた周 波数一波数スペクトルのピークから伝播速度を求め, そ れらを平均して最終的な伝播速度とした。 その際に, 解 析対象とする微動の最大波長を最大地震計間隔の約 3 倍とした。

得られた伝播速度はFig. 3 に示されている. 両地点に おいて周期 0.5 秒より長周期帯域で明瞭に正分散性が認 められ，レイリー波の位相速度であると解釈できる. 短 周期での位相速度は, 両地点とも $0.7 \mathrm{~km} / \mathrm{s}$ とほぼ同程 


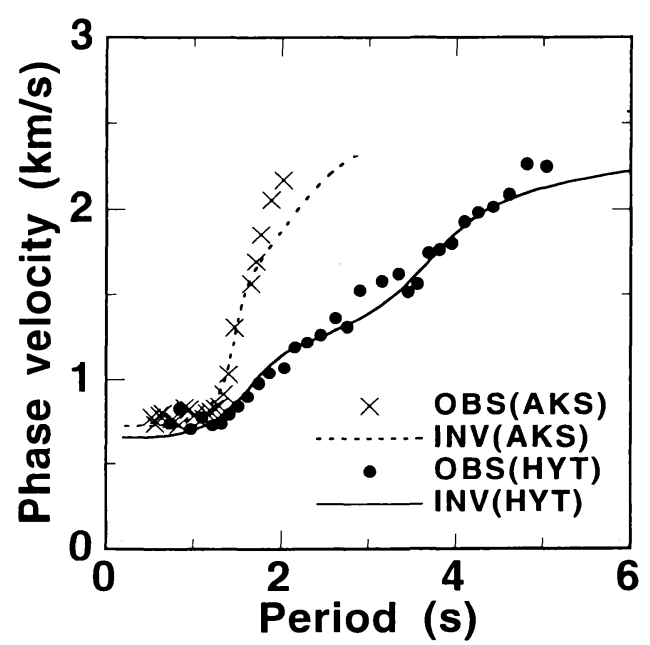

Fig. 3. Phase velocities of microtremors observed at HYT (circles) and AKS (crosses). Solid and broken lines indicate theoretical phase velocities of fundamental mode of Rayleigh waves for inverted models shown in Fig. 5.

度であり, 表層の $\mathrm{S}$ 波速度が類似していることを示唆し ている. しかし，周期 1.5 秒より長周期帯域では両者は 大きく異なり, AKS での位相速度は, 周期の増加に伴い 急に大きくなっている. 定性的には, AKS ではHYTに 比べて堆積首が薄くなっていることを示している。

不整形な地盤を波動が伝播する場合には，表面波の位 相速度に方位依存性がみられることが数值解析に基づ く検討から指摘されている[例えば，BOORE (1972), FUJIWARA (1997)]. 今回得られた位相速度と伝播方向 の関係の例が Figs. $4 \mathrm{a}$ と $4 \mathrm{~b}$ に示されている. ほとんど の周期成分に対して推定された位相速度は全方位に分布 していないので, 今回の結果だけでは明確に方位依存性 の有無についてを判断することはできない。しかし， AKS での周期約 1 秒の成分や HYT での周期約 2 秒の 成分のように, 立川断層の走行方向之その直交方向に微 動が伝播した場合では，位相速度に顕著な差異は認めら れないことがわかる. FUJIWARA (1997)による数値計算 では，境界面が傾斜している地域に対して計算されたレ イリー波の位相速度は，直下の成層構造に対する理論位 相速度と異なることが指摘されている. 今回, 観測が行 われたアレイでは，その直下に断首が存在する可能性は 少ない，したがって，今回の結果は，断層付近ではあっ ても，アレイ内に急激な地下構造の变化が含まれなけれ ば，位相速度の方位依存性はあまり大きくないことを示 唆している.

\section{3 位相速度の逆解析}

つぎに，観測された位相速度に対して遺伝的アルゴリ

\section{HYT ARRAY}
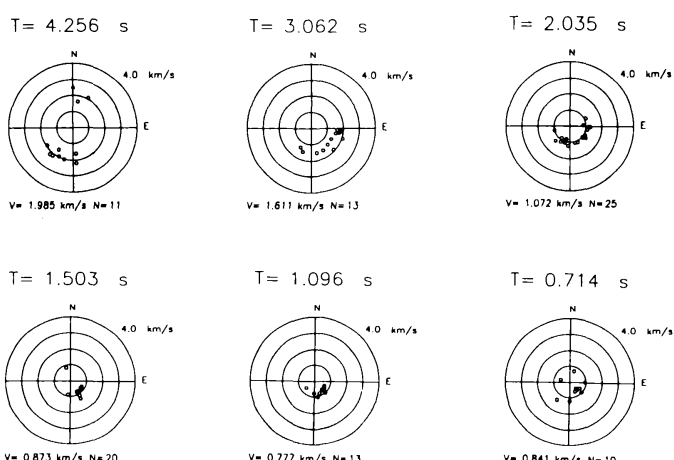

Fig. 4a. Relationships between propagation directions and phase velocities at HYT. Each small circles indicate velocity and direction of microtremors for each data.

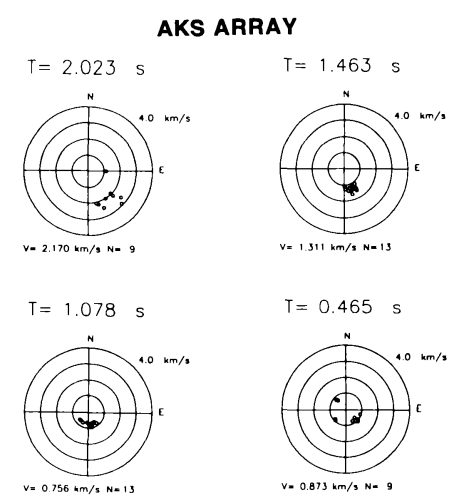

Fig. 4b. Relationships between propagation directions and phase velocities at AKS. Each small circles indicate velocity and direction of microtremors for each dataset.

ズムによる逆解析［山中・石田(1995)］を行い， S 波速 度構造を推定する. 逆解析では, 山中・他 (1999) 之同様 に関東平野での地質構成を考慮して，4層からなる平行 成層モデルを仮定した. 各層の $\mathrm{S}$ 波速度と層厚を变数と して, 観測された位相速度の值と基本モードのレイリー 波の位相速度の理論值との差の $\mathrm{L}_{1}$ ノルムが最小になる モデルを探索する. 各变数に対する探索範囲は Table 1 に示されている. 逆解析での未知数以外の地盤定数につ いては, P 波速度を経験式により $\mathrm{S}$ 波速度と連動させ, 密度を Table 1 に示した值に固定した。 ただし, 既往の 地震探查の結果 [嶋・他 (1981)］の結果を参考にして, 最下層の $\mathrm{S}$ 波速度を $3 \mathrm{~km} / \mathrm{s}$ に拘束した。遺伝的アルゴ リズムによる逆解析では山中・他 (1999) 之同様の考え 方にしたがって, 乱数の初期值を変えて, 10 回の試行を 行ない，探索されたすべてのモデルのなかから㕵差の小 
Table 1. Search limits in genetic inversion of phase velocity.

\begin{tabular}{cccc}
\hline \hline No. layer & $V_{\mathrm{s}}(\mathrm{km} / \mathrm{s})$ & $H(\mathrm{~km})$ & $\rho\left(\right.$ ton $\left./ \mathrm{m}^{3}\right)$ \\
\hline 1 & $0.3-0.8$ & $0.01-1.0$ & 1.8 \\
2 & $0.7-1.2$ & $0.01-1.5$ & 2.0 \\
3 & $1.0-1.8$ & $0.01-2.0$ & 2.3 \\
4 & 3.0 & $\infty$ & 2.5 \\
\hline
\end{tabular}

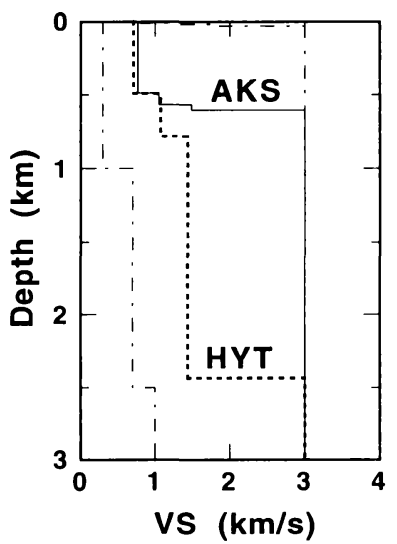

Fig. 5. Subsurface structures of deep sediments inverted from the phase velocities shown in Fig. 3. The solid and the dotted lines indicate subsurface structural models deduced at AKS and HYT. Dashed-anddotted lines show limits of search area of parameters in the inversions.

さいモデル集団を求め, それらのパラメー夕の分布から 解の収束状况を判断した後に, 平均値を最適モデルとし た.

得られた $\mathrm{S}$ 波速度分布を Fig. 5 に示す. 両地点では 深さ $0.5 \mathrm{~km}$ までは，ほぼ同じ地下構造であるが，それ 以深で大きく異なっている，HYTでは，S 波速度 1.5 $\mathrm{km} / \mathrm{s}$ を有する層が $1.5 \mathrm{~km}$ 以上の厚さで存在し, 基盤 深さは約 $2.5 \mathrm{~km}$ となっている. 一方, AKS では, 深さ 約 $0.7 \mathrm{~km}$ で基盤に達している. 観测された位相速度と Fig. 5 に示されている逆解析モデルに対するレイリー波 の位相速度の比較は Fig. 3 のごとくであり, 逆解析モデ ルによって両地点とも観測値がよく説明できていること がわかる.

\section{§ 3. 昭島における人工地震の走時解析}

\section{1 人工地震データの概略}

立川断層周辺での人工地震探查は, 1984 年 3 月 11 日に東京都昭島市多摩川の河川敷を発破点として行われ た. 発破と観測条件や観測記録については，瀬尾 (1987)
や首都圈基盤構造研究グループ (1989) によって報告さ れている. 観測点は発破点から 4 方向に設けられたが, ここでは北東一南西方向に展開された高尾一所沢測線で の観測結果に注目する. 同測線でのいくつかの観測点と 発破点の位置はFig. 1 に示されている. 高尾一所沢測線 の南西端である高尾では, 関東山地に位置しており, 岩 盤がほぼ露頭となっている地域である。一方, 震央から 北東の所沢に向かうにしたがって, 堆積層の厚さは増加 していると考えられる.

解析に際しては初動の到着時刻を読み直した，参考に した観測記録の出力波形は夢の島人工地震実験資料集 [首都圈基盤構造研究グループ (1989)] に掲載されてい る. 読み取った初動および後続位相の走時データは Table 2 にまとめられている. いくつかの点を除いて, 首都圈基盤構造研究グループ (1989) によって報告され ている值とほぼ同様であった。

\section{2 タイムターム法による解析}

Fig. 6 は高尾一所沢測線で得られた走時曲線を示して いる. 震源近傍で得られた初動と後続位相の走時から堆 積層を伝播した直達波の見かけ速度を求めると, 2.1 $\mathrm{km} / \mathrm{s}$ から $2.3 \mathrm{~km} / \mathrm{s}$ に分布しており, 平均的には $\mathrm{P}$ 波 速度 $2.2 \mathrm{~km} / \mathrm{s}$ を有する堆積層があると考えられる．基 盤層を伝播した $\mathrm{P}$ 波初動の走時によれば，見かけ速度が 震源から北東側で $4.4 \mathrm{~km} / \mathrm{s}$ で, 南西側では $5.6 \mathrm{~km} / \mathrm{s}$ となっている．逆発破の観測が行われていないので，基 盤の真の速度を求めることは難しい. しかし，基盤が一 様傾斜していると仮定すれば，基盤の $\mathrm{P}$ 波速度（以下， $\left.V_{\mathrm{p}}\right)$ は $5.0 \mathrm{~km} / \mathrm{s}$ であると考えられる.これは, 既往の研 究結果 [山中・他 (1988)] で明らかにされている $V_{\mathrm{p}} 4.8$ $\mathrm{km} / \mathrm{s}$ 層に近い屯のであると考えられる. 所沢に向かう 万向の測線の震央距離 $6 \mathrm{~km}$ 付近から,この $V_{\mathrm{p}} 5.0 \mathrm{~km} /$ $\mathrm{s}$ 層を伝播した初動の到着が遅れはじめ, さらに約 10 $\mathrm{km}$ を過ぎて, 初動走時は $5.0 \mathrm{~km} / \mathrm{s}$ と再び同程度の見 かけ速度となる。こうした走時の遅れは，基盤に断差構 造がある場合に考えられる特徵的な走時曲線である. し かむ, 走時遅れが生じる位置は立川断層の位置と一致し ていることから，立川断層の存在による初動走時遅れで あると考えられる.この場合には北東方向に基盤が落ち ていることになる.

Fig. 7 は高尾-所沢測線でのタイムタームの分布を示 している. $V_{\mathrm{p}} 5.0 \mathrm{~km} / \mathrm{s}$ 層までのタイムタームは, 所沢 に向かった方向での震央距離数キロの地点から急に大き くなり, $10 \mathrm{~km}$ を過ぎた地点より遠くでほぼ一定になっ ている．このタイムタームの分布はおよその立川断層周 辺地域での基盤の形状を表していると考えられる。一 方, 高尾に向かった方向では, $V_{\mathrm{p}} 5.0 \mathrm{~km} / \mathrm{s}$ 層までの夕 
Table 2. Travel time data from Akishima explosion.

\begin{tabular}{|c|c|c|c|c|c|}
\hline \multirow{2}{*}{ No. } & \multicolumn{2}{|c|}{ Location } & \multirow{2}{*}{$\begin{array}{c}\text { Distance } \\
(\mathrm{km})\end{array}$} & \multicolumn{2}{|c|}{ Travel time (s) } \\
\hline & Latitude & Longitude & & Initial phase & Later phase \\
\hline 0 & $35^{\circ} 41^{\prime} 33.0^{\prime \prime}$ & $139^{\circ} 21^{\prime} 07.5^{\prime \prime}$ & 0.0 & & \\
\hline 1 & $35^{\circ} 46^{\prime} 54.3^{\prime \prime}$ & $139^{\circ} 27^{\prime} 49.1^{\prime \prime}$ & 14.14 & 3.99 & $4.22,5.00$ \\
\hline 2 & $35^{\circ} 46^{\prime} 21.1^{\prime \prime}$ & $139^{\circ} 27^{\prime} 08.4^{\prime \prime}$ & 12.69 & 3.71 & $4.09,4.19$ \\
\hline 3 & $35^{\circ} 45^{\prime} 42.6^{\prime \prime}$ & $139^{\circ} 26^{\prime} 42.1^{\prime \prime}$ & 11.39 & 3.50 & 3.66 \\
\hline 4 & $35^{\circ} 45^{\prime} 24.3^{\prime \prime}$ & $139^{\circ} 26^{\prime} 09.4^{\prime \prime}$ & 10.41 & 3.32 & $3.66,5.21,5.90$ \\
\hline 5 & $35^{\circ} 45^{\prime} 05.3^{\prime \prime}$ & $139^{\circ} 25^{\prime} 40.7^{\prime \prime}$ & 9.48 & 2.95 & $3.55,5.57$ \\
\hline 6 & $35^{\circ} 44^{\prime} 54.5^{\prime \prime}$ & $139^{\circ} 25^{\prime} 21.8^{\prime \prime}$ & 8.91 & 2.74 & $3.05,3.85,5.36$ \\
\hline 7 & $35^{\circ} 44^{\prime} 20.0^{\prime \prime}$ & $139^{\circ} 24^{\prime} 54.9^{\prime \prime}$ & 7.69 & 2.33 & $2.81,3.46,4.49$ \\
\hline 8 & $35^{\circ} 43^{\prime} 55.3^{\prime \prime}$ & $139^{\circ} 24^{\prime} 25.0^{\prime \prime}$ & 6.62 & 2.05 & 3.69 \\
\hline 9 & $35^{\circ} 43^{\prime} 45.2^{\prime \prime}$ & $139^{\circ} 23^{\prime} 46.7^{\prime \prime}$ & 5.71 & 1.79 & \\
\hline 10 & $35^{\circ} 43^{\prime} 15.0^{\prime \prime}$ & $139^{\circ} 23^{\prime} 23.6^{\prime \prime}$ & 4.65 & 1.56 & 2.10 \\
\hline 11 & $35^{\circ} 42^{\prime} 58.5^{\prime \prime}$ & $139^{\circ} 22^{\prime} 58.0^{\prime \prime}$ & 3.83 & 1.36 & $1.94,2.20$ \\
\hline 12 & $35^{\circ} 42^{\prime} 44.1^{\prime \prime}$ & $139^{\circ} 22^{\prime} 25.1^{\prime \prime}$ & 2.93 & 1.18 & 1.70 \\
\hline 13 & $35^{\circ} 42^{\prime} 12.3^{\prime \prime}$ & $139^{\circ} 22^{\prime} 05.4^{\prime \prime}$ & 1.89 & 0.92 & 1.02 \\
\hline 14 & $35^{\circ} 41^{\prime} 50.5^{\prime \prime}$ & $139^{\circ} 21^{\prime} 22.6^{\prime \prime}$ & 0.66 & 0.29 & \\
\hline 15 & $35^{\circ} 41^{\prime} 03.9^{\prime \prime}$ & $139^{\circ} 20^{\prime} 20.2^{\prime \prime}$ & 1.49 & 0.61 & 0.83 \\
\hline 16 & $35^{\circ} 40^{\prime} 33.3^{\prime \prime}$ & $139^{\circ} 19^{\prime} 54.0^{\prime \prime}$ & 2.61 & 1.03 & $1.31,1.43$ \\
\hline 17 & $35^{\circ} 40^{\prime} 02.6^{\prime \prime}$ & $139^{\circ} 19^{\prime} 06.2^{\prime \prime}$ & 4.13 & 1.24 & $1.80,2.10$ \\
\hline 18 & $35^{\circ} 39^{\prime} 27.7^{\prime \prime}$ & $139^{\circ} 18^{\prime} 23.9^{\prime \prime}$ & 5.64 & 1.55 & \\
\hline 19 & $35^{\circ} 38^{\prime} 57.2^{\prime \prime}$ & $139^{\circ} 17^{\prime} 28.6^{\prime \prime}$ & 7.30 & 1.85 & \\
\hline 20 & $35^{\circ} 38^{\prime} 06.8^{\prime \prime}$ & $139^{\circ} 16^{\prime} 59.6^{\prime \prime}$ & 8.90 & 2.08 & \\
\hline 21 & $35^{\circ} 37^{\prime} 41.3^{\prime \prime}$ & $139^{\circ} 16^{\prime} 13.0^{\prime \prime}$ & 10.29 & 2.32 & \\
\hline 22 & $35^{\circ} 36^{\prime} 50.7^{\prime \prime}$ & $139^{\circ} 15^{\prime} 09.4^{\prime \prime}$ & 12.52 & 2.73 & \\
\hline
\end{tabular}

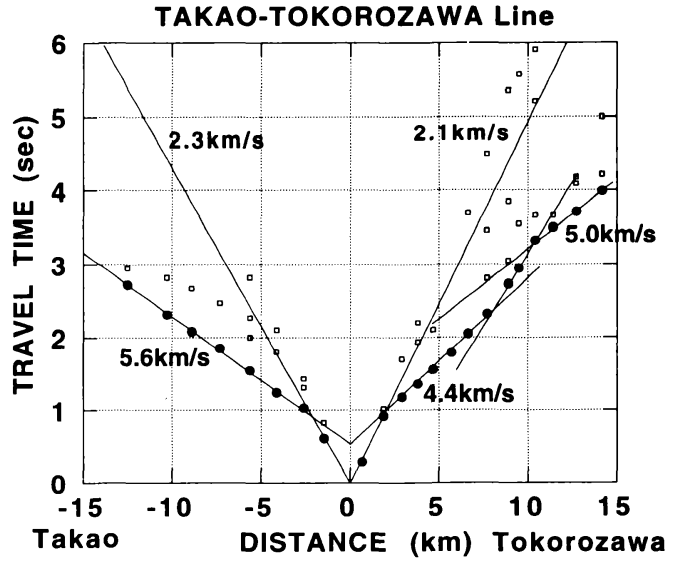

Fig. 6. Travel time diagrams of initial and later phases in explosion records at sites between Takao and Tokorozawa obtained during an explosion at Akishima, Tokyo. The travel time data were listed in Table 2.

イムタームは徐々に小さくなり, 震央距離約 $8 \mathrm{~km}$ より 南西側の高尾付近ではほぼ 0 秒で， $V_{\mathrm{p}} 5.0 \mathrm{~km} / \mathrm{s}$ 層がほ ぼ露頭となっていると考えられる.

上記のように得られたタイムタームの分布をあとに, 地下構造を決定する. まず, 堆積層内部の速度構造をュ
ニークに決定することはできないので, 堆積層は $V_{\mathrm{p}} 2.2$ $\mathrm{km} / \mathrm{s}$ を有する 1 層であると仮定する. すると， $V_{\mathrm{p}} 5.0$ $\mathrm{km} / \mathrm{s}$ 層までのタイムタームを約 2.5 倍することにより $V_{\mathrm{p}} 2.2 \mathrm{~km} / \mathrm{s}$ 層の厚さを求めることができ, 得られた地 下構造は Fig. 7 のごとくである. 高尾付近で $V_{\mathrm{p}} 5.0$ $\mathrm{km} / \mathrm{s}$ を有する基盤層は地表付近に存在し, 所沢に向 かって徐々に深くなり, 昭島発破点では基盤層までの深 さは約 $0.6 \mathrm{~km}$ となる.さらに，立川断層の手前では基 盤深さは約 $0.9 \mathrm{~km}$ となり, 立川断首の位置で基盤が北 東方向に約 $1.3 \mathrm{~km}$ の落差を持ち, さらに, その北東側 では基盤層までの深さは約 $2.2 \mathrm{~km}$ でほぼ一定となる.

\section{§4. レイトレーシングによる人工地震データの解析}

\section{1 タイムターム解析によるモテル}

地層の傾斜が大きい場合，一般にタイムターム法によ る屈折波初動の走時解析では適切に地下構造を求めるこ とが難しい [例えば, BATH (1978)]. 今回の解析におい ても立川断層付近では，基盤の傾斜は大きいと考えられ るので, タイムターム法に基づく解析により得られた地 下構造の妥当性の検討をレイトレーシングにより行うこ とにする.レイトレーシングには, QIN et al. (1992) を参 考にして, 初動走時をアイコナール方程式の差分近似に 


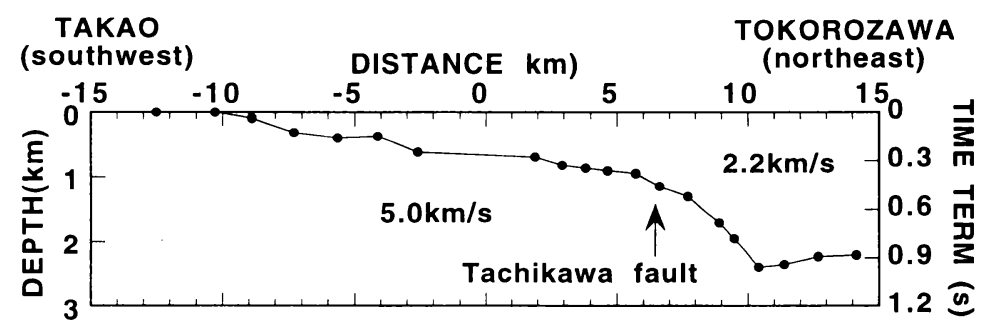

Fig. 7. Distribution of the time term and P-wave velocity model along Takao-Tokorozawa line from the time term analysis of the seismic refraction data in Fig. 6.

TAKAO-TOKOROZAWA Line

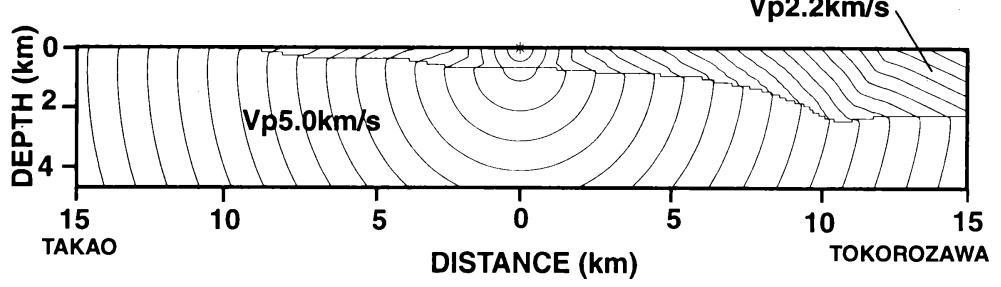

Fig. 8. Wave front of initial phase in subsurface structural model derived from the time term analysis. Contours are depicted with a travel time interval of $0.2 \mathrm{sec}$. The asteriak indicates the source location.

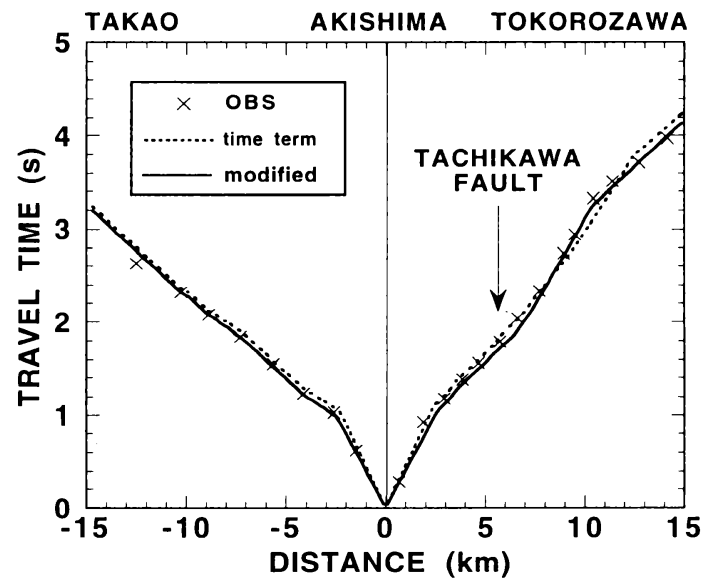

Fig. 9. Comparison of observed travel time of initial phases (crosses) with theoretical ones calculated for the model shown in Fig. 8 shown (broken line). Travel times shown by a solid line are calculated travel times of initial phases for the model shown in Fig. 11.

より求める方法を用いた。この方法では, 断層などによ る回折波の影響む評価することができることが特徴であ る.

タイムターム法に基づく解析から得られた地下構造モ デルに対して計算された初動の波面が Fig. 8 に示され ている. 初動の波面から, 震央距離 $2 \mathrm{~km}$ 程度より遠く の地点において屈折波が初動となっていることがわか
る. また, 断層付近では, その幾何学的形状により波面 が曲げられている.さらに，震央距離約 $12 \mathrm{~km}$ より遠く の地点では基盤の落ちた部分からの屈折波が初動となっ ている. 計算された初動走時（波線）と観測走時の比 較は Fig. 9 に示されている. 断層の北東側の震央距離 11 15 km の観測点に対する計算結果では, 断層の存 在により初動の到着時間に遅れが生じている。しかし， 震央距離約 9 および $10 \mathrm{~km}$ の地点で観測された初動の 到着時間が十分に説明できていない，多ムターム法に よる初動走時の解析では回折波の影響が考慮されず，正 確に初動の波線がトレースされていないので，適切に地 下構造が得られていないことを示している。，一方，断層 の南西側では，地下構造モデルに急激な変化がないの で, 理論值と観測值はほぼ一致しており，タイムターム 法による解析結果が妥当であることがわかる.

\section{2 修正モデル}

前述の微動アレイ観測の結果を考慮して，立川断層の 北東側の地下構造モデルを修正するために, 人工地震の 走時データの再解析を試みる. 微動アレイ観測の結果に よれば，堆積層の厚さは立川断層を境に急に変化してい る可能性が高い，そこで，以下のような考えに基づき， 立川断層の北東側の地下構造モデルを Fig. 10 の実線の ように修正する。タイムターム法に基づく解析から得ら れたモデルでは, 地表の立川断層の位置から北東に向 かって約 $5 \mathrm{~km}$ の間で, 基盤は緩やかに傾斜している. 修正モデルでは，この間の部分を HYTにおける微動了 
レイの結果を参考にして基盤深さを $2.5 \mathrm{~km}$ とする.つ まり, 地表での断層位置から微動アレイの最南西端の位 置までの間の距離約 $2 \mathrm{~km}$ の間で基盤深度が $1.6 \mathrm{~km}$ だ け急に深くなり, 微動アレイ直下では基盤深さが 2.5 $\mathrm{km}$ になるとした. つぎに, 堆積層の平均的な $\mathrm{P}$ 波速度 を微動アレイ観測の結果から得られた堆積層の層構成を 考虑して $2.5 \mathrm{~km} / \mathrm{s}$ とする. すなわち, HYT での地下構 造での堆積層の層厚を重みにして, 堆積層の $\mathrm{P}$ 波速度を 平均することにより平均的な $\mathrm{P}$ 波速度とした。

この修正モデルに対して計算された初動の波面は Fig. 11 に示されている. 基盤の傾斜が大きくなり, 断層 付近での波面の曲がりがより顕著になっている．この初 動の波面の曲がりは, 基盤の断層上部のエッジで発生し た回折波によるものである。この回折波は震央距離 7 $\mathrm{km}$ 付近より遠くの地点で初動となっている. 修正モデ ルに対する初動の理論走時は Fig. 9 の実線のごとくで ある. 修正モデルによって震央距離 7〜11 km での地点 での観測走時の遅れがよく説明できている.したがっ て, 断層部分については, 修正モデルのほうがタイム

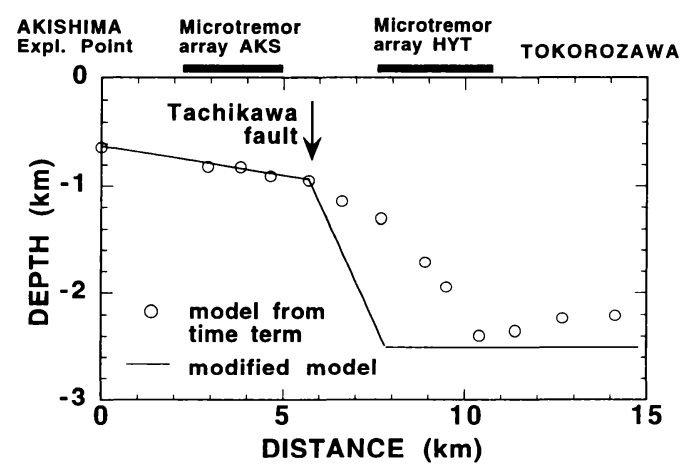

Fig. 10. Modification of subsurface structural model with a consideration of results of microtremor array measurements shown in Fig. 5. Circles indicate the basement depths derived by the time term method and the solid line shows that in the modified model.
ターム法によるモデルに比べてより観測走時を説明して おり, より現実に近い地下構造モデルであると考えられ る.なお, 初動の読み取り誤差は, 0.03 秒程度であり, 修正モデルが十分に有為な差で断層による走時遅れを説 明していると考えられる。

\section{§5. 議論}

\section{1 立川断層の地下構造について}

立川断層は地形学的調查から北東側が隆起している断 層であると考えられている [山崎 (1978)]. 一方, 同地域 の重力異常の分布からは逆に基盤面が南西側に隆起して いると解釈されている [多田 (1983)]. 多田 (1983) はこ の食い違いについて地形学的調査から求められる新しい 時代の断層運動が古い時代のそれと異なっていることに よるとしている.その後に立川断層付近で密度の高い重 力測定が実施された。一般に，こうした重力異常の分布 のみによって基盤層までの深さの絶対值を精度よく知る ことは難しいが, 断層の北部では地形調查の結果と同様 に北東隆起であり, 南部では南西隆起であることが指摘 された [萩原・他 (1988a), 萩原・他 (1988b)].

立川断層周辺での人工地震探查として，笠原・他 (1976) は立川断層を横切る埼玉県吉川町から五日市に 至る測線で人工地震の観測を行っている. そのデータの 解釈から得られた地下構造モデルによれば［多田 (1982)], $\mathrm{P}$ 波速度 $5.5 \mathrm{~km} / \mathrm{s}$ を有する基盤層が立川断首 の西の五日市に向かって浅くなるような構造が得られて いるが，観測点が少ないために立川断層の形状について はあまり議論されていない.さらに, 多田 (1983) は重力 異常のデータも加味して, 北東落ちの基盤段差構造を求 めている. 以上の重力探查之屈折法地震探査の結果は今 回の結果と定性的には一致する結果である.

今回の解析では基盤の $\mathrm{P}$ 波速度を $5.0 \mathrm{~km} / \mathrm{s}$ であると し, 既往の人工地震探査の結果で示されている $V_{\mathrm{p}} 4.8$ $\mathrm{km} / \mathrm{s}$ に近いものであると考えた. 山中・他(1988)によ れば，今回の探査地域は $V_{\mathrm{p}} 4.8 \mathrm{~km} / \mathrm{s}$ 層が顕著な厚さで

\section{TAKAO-TOKOROZAWA Line}

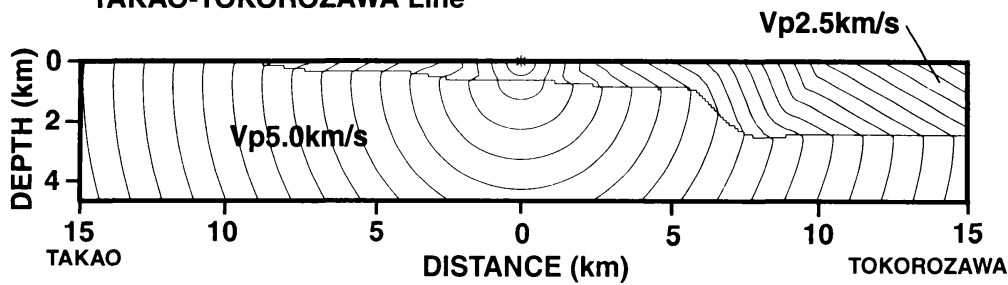

Fig. 11. Wave front of initial phase in the modified subsurface structural model shown in Fig. 10. Contours are depicted with a travel time interval of $0.2 \mathrm{sec}$. The asteriak indicates the source location. 
存在する北限であり, その結果と矛盾はしない。しかし， $5.0 \mathrm{~km} / \mathrm{s}$ という值が真の基盤速度であるかについては 今後さらなる検討が必要である。 また, 関東平野で広く 認められている 5.3 ないし $5.6 \mathrm{~km} / \mathrm{s}$ の $\mathrm{P}$ 波速度を有す る基盤は，今回の $V_{\mathrm{p}} 5.0 \mathrm{~km} / \mathrm{s}$ 層の下に存在するあのと 考えられる.

最近，いくつかの反射法地震探査が立川断層周包で行 われている．山口・他 (1998) による Fig. 1 に示す反射 法地震探査測線での $\mathrm{P}$ 波速度断面の解釈によれば, 浅部 の新しい年代の地層は，立川断層を境にして南西落ちで あるが，基盤は北東落ちであり，今回の結果と定性的に は矛盾しない，樑さ $0.6 \mathrm{~km}$ 程度までの反射断面では, 断層の両側での各境界面の深度は $0.1 \mathrm{~km}$ 程度の差はあ るが，ょく対応している. 今回の微動アレイ観測の結果 でも，その深さまでは断層の両側でほぼ類似した S 波速 度構造であり, 反射法地震探查の結果とは調和的であ る. 一方, 反射断面での基盤深さは，断層の西側で 0.8 $0.9 \mathrm{~km}$ となっており，微動アレイ観測の結果とはほぼ 一致している.しかし，断層の東側での反射断面では， 基盤深さは $1.1 \mathrm{~km}$ であり，微動観測から得られた基盤 深さ $2.5 \mathrm{~km}$ に比べて浅くなっている．東側では基盤深 度が深く，反射波の $\mathrm{S} / \mathrm{N}$ 比が低くなっており，基盤がよ り深くなっている可能性も指摘されている [山口・他 (1998)]．東京都 (1998) による反射法地震探查の結果 あ, 山口・他 (1998) の結果と類似しており, 立川断層の 東側での基盤上面からの反射波は明確ではない，いずれ にせよ, 既往の研究結果と比較して，今回得られた基盤 の落差の絶対量についての妥当性を確認することは現時 点では難しい.

\section{2 立川断層周辺での地盤增幅特性について}

上記の検討から得られた立川断層の地下構造モデルを 用いて，基盤の段差構造付近での地震波の挙動について 検討する．計算は 2 次元 P-SV 場に対する有限差分法を 用いて，Fig. 12 のような地下構造モデルに対して行わ れた. 断差近傍での基盤構造は走時解析による修正モデ ルとし，その両側における堆積層構造は微動アレイによ る S 波速度構造とした. 入射波としては，鉛直に入射す る周期 1.0 秒のサイン波 1 周期の平面 SV 波を仮定し た。

Fig. 13 には, 地表面での水平および上下成分の計算 波形が示されている，段差の落ちた側に位置する地点で 後続位相が顕著に現われている. とくに，上下成分では 位相速度の小さいレイリー波による後続位相が顕著であ る.Fig. 14 には, 入射波に対する地表での波形の最大振 幅の比が示されている，水平動成分については段差から 約 $2.5 \mathrm{~km}$ 離れた地点で振幅比が断層の南西側の約 1.5

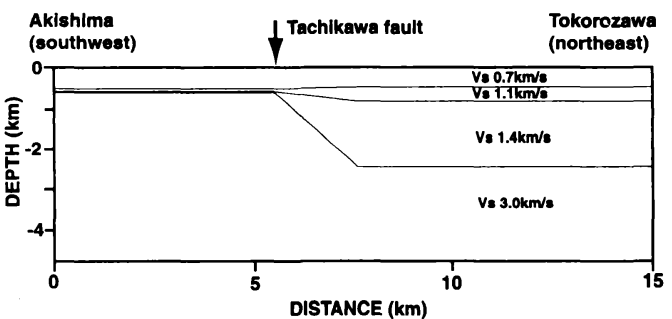

Fig. 12. S-wave structural model used for the finite difference simulation of earthquake ground motion.
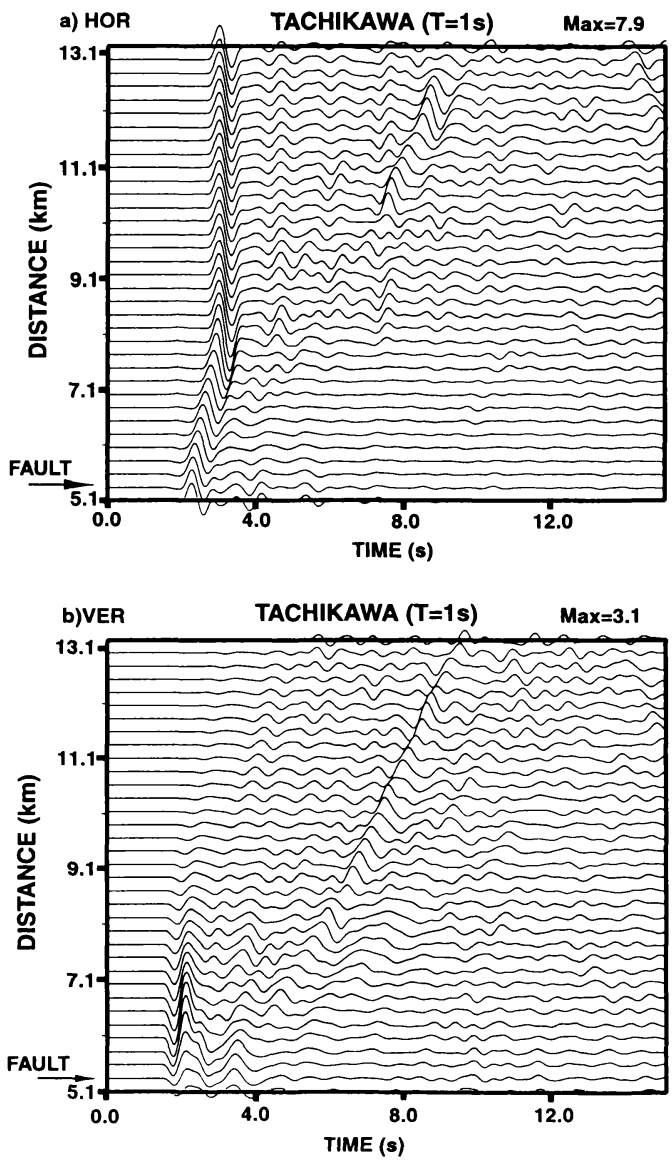

Fig. 13. Calculated ground motions due to vertical SV-wave incidence for a) horizontal and b) vertical components. Amplitude of each trace is normalized by each maximum value of all traces.

倍となっている、スナップショットで確認したところ, これは段差により伝播経路が曲げられた S 波と直達 S 波の増幅的干渉によると考えられる，上下動成分では段 差から約 $1 \mathrm{~km}$ の地点で振幅比が最大となる．この位置 での最大值は，基盤上面で $\mathrm{S}$ 波から変換した $\mathrm{P}$ 波によ 


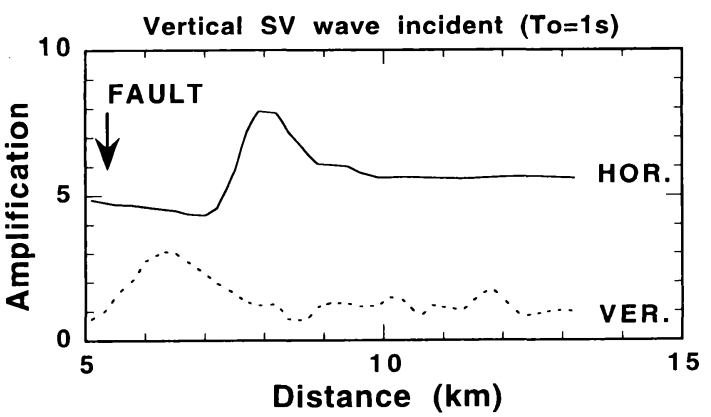

Fig. 14 Ratios of maximum amplitude of calculated motions due to vertical SV-wave incidence. Solid and dotted lines indicate the ratios of horizontal and vertical motions, respectively.

るあのである. しかし, 段差からより離れた地点ではレ イリー波が最大値を示すようになる.

\section{6. ま と め}

東京都西部に存在する立川断層周辺において微動アレ イ観測を行ない， $\mathrm{S}$ 波速度 $3 \mathrm{~km} / \mathrm{s}$ を有する基盤に至る までの $\mathrm{S}$ 波速度構造を明らかにした，深さ $0.6 \mathrm{~km}$ 程度 までは，断層の両側ではほぼ同じ構造であるが，基盤深 度は断層の南西側では $0.9 \mathrm{~km}$ で, 北東側では $2.5 \mathrm{~km}$ となっている，さらに，既往の人工地震による初動走時 データに対してレイトレーシングによる解析を行ない, 微動アレイ観測の結果を考虑して断層に直交する方向で の 2 次元地下構造モデルを作成した，得られた地盤モデ ルを用いて, 地震波伝播の数值シミュレーションを行 い，基盤の段差構造により地震波の増幅的干涉が起こ り，段差の落ちた側で振幅が大きくなることがわかっ た. 今後, 立川断層周辺での地震観測の結果に対しても, 地下構造や地盤増幅特性の観点から同様の検討を行う予 定である.

\section{謝辞}

嶋 悦三東京大学名誉教授には, 地下構造に関してご 助言を頂きました，東京工業大学衣笠善博博士には，原 稿を読んで頂き，ご助言して頂きました，微動観测に際 しては, 東京都土木研究所の中山俊雄氏をはじめとし て，多くの機関の方々にご協力を頂きました．東工大瀬 尾および山中研究室の大学院生の方々に観測にご協力を 頂きました．地質調查所の横倉隆伸博士および山口和雄 博士には, 反射法地震探查の結果について教えて頂きま した．大阪工業大学掘家正則博士および東京都立大学山 崎晴雄博士には查読して頂きました。記して感謝いたし
ます．本研究の一部は文部省科学研究費補助金（課題番 号 09234209 と09305036）を受けて実施されました.

\section{文献}

BÅтн, M., 1978, An analysis on the time term method in refraction seismology, Tectonophysics, 51, 155169.

Boore, DM, 1972, Finite difference method for seismic wave propagation in heterogeneous materials, Methods in Computational Physics, 11, 1-37.

CAPON, J., 1969, High resolution frequency wavenumber spectrum analysis, Proc. IEEE, 57, 1408-1418.

Fujiwara, H., 1997, Windowed f-k spectra of a threedimensional wavefield excited by a point source in a two-dimensional multilayered elastic medium, Geophys. J. Int., 128, 571-584.

香川敬生・澤田純夫・岩崎好規・南草 淳, 1993, 大阪 堆積盆地における深部地下構造のモデル化, 第 22 回 地震工学研究発表会, 199-202.

笠原敬司・鈴木宏芳・高橋 博, 1976, 東京西部地区基 盤構造について 1 , 昭和 51 年度地震学会春季大会講 演予稿集, No. 1, 139.

KAsugA, S. and K. IRIKuRA, 1982, Lateral variation of ground motions on surface layers with a horizontal discontinuity, Proc. 6th Japan Earthquake Engineering Symposium, 65-72.

活断層研究会, 1980 , 日本の活断層一分布図之資料一日 本と周辺海域の活断層図, 東京大学出版会.

川瀬 博・林 康裕, 1996, 兵庫県南部地震時の神戸市 中央区での基盤波の逆算とそれに基づく強震動シミュ レーション, 日本建築学会構造系論文報告集, 480, 67-76.

Kohketsu, K. and S. Higashi, 1992, Three-dimensional topography of the sediment/basement interface in the Tokyo metropolitan area, central Japan, Bull. Seism. Soc. Am., 82, 2328-2349.

工藤一嘉 - 鹿熊英昭 - 坪井大輔 - 笹谷 努 - 高橋正義 神野達夫, 1997, 機動強震観測のための過減衰・動コ イル型強震計の開発と性能試験, 日本地震学会講演予 稿集 1997 年度秋季大会, P12.

栗田勝実・山中浩明, 1998, 立川断層周辺における地震 観測, 物理探査学会第 98 回学術講演論文集, 289291.

萩原幸男 - 長沢 工・井筒屋貞勝 - 小竹美子 - 大久保修 平, 1988a, 活断層の重力調查 (3)一越生一高麗本郷断 層之立川断層北部一, 地震研究所彙報, 63, 33-50.

萩原幸男・村田一郎 - 長沢 工・井筒屋貞勝 - 小竹美 子・大久保修平, 1988 b, 活断層の重力調查 (4)一立川 断層の検出一, 地震研究所彙報, 63, 115-129.

Qin, F., Y. Luo, K. B. Olsen, W. CAI and G. T. SchusTER, 1992, Finite-difference solution of the eikonal equation along expanding wavefronts, Geophysics, 57, 478-487.

佐藤俊明・R. GRAVES - P. SOMMERVILLE, 1997, 関東平 野の 3 次元堆積盆地構造を考慮した 1990 年小田原地 震 $\left(M_{\mathrm{j}}=5.1\right)$ およよ゙ 1923 年関東大地震 $\left(M_{\mathrm{s}}=8.2\right)$ の 
地震波動シミュレーション, 日本地震学会シンポジゥ ム, 「強震動予測による地震災害の軽減をめざして」, 55-58.

首都圏基盤構造研究グループ, 1989 , 夢の島人工地震実 験資料集.

瀬尾和大，1987，関東平野直下の基盤構造と地震動特 性, 文部省科学研究費自然災害科学特別研究成果, No. A-61-2, 関東平野直下の地震活動および地震動 予測についての基礎的研究(代表: 宇佐美龍夫), 171186.

嶋 悦三・柳沢馬住・工藤一嘉・瀬尾和大, 1981, 東京 の基盤構造その 5, 第 7 回, 第 8 回, 第 9 回夢の島爆 破による地下深部探查, 地震研究所彙報, 56, 265276 .

多田 堯, 1982, 関東平野の基盤構造と重力異常 (1)基盤深度図一，地震 $2 ， 35,607-617$.

多田 堯, 1983, 関東平野の基盤構造之重力異常 (2)活断層の地球物理学研究一, 地震 $2,36,357-372$.
東京都, 1998, 平成 9 年度地震関係基礎調査交付金, 立 川断層に関する調查成果報告書, 東京都.

山口和雄 - 加藤直己・横倉隆伸 - 木口 努 - 田中明子 佐藤比呂志, 1998, 反射法による立川断層の地下構 造, 活断層研究, 17, 54-64.

山中浩明・瀬尾和大・佐間野隆憲・翠川三郎・嶋 悦 三・柳沢馬住, 1988 , 人工地震による首都圈南西部の 地下深部探查 $(3)-1983,1984$ 年に実施された人工地 震デー夕の総合的解析一, 地震 $2,41,527-539$.

山中浩明・石田 寛, 1995, 遺伝的アルゴリズムによる 位相速度の逆解析, 日本建築学会構造系論文報告集, 468, 7-19.

山中浩明・佐藤浩章・栗田勝実・瀬尾和大, 1999, 関東 平野南西部におけるやや長周期微動のアレイ観測一横 浜市および川崎市における $\mathrm{S}$ 波速度構造の推定一, 地 震 $2,51,355-365$.

山崎晴雄, 1978, 立川断層之その第四紀後期の運動, 第 四紀研究，16,231-246. 